\title{
Performance Evaluation of Ordinary Portland Cement with GGBFS and Portland Slag Cement at Same GGBFS Replacement Level in Concrete
}

\author{
Ramesh Babu Chokkalingam ${ }^{1, *}$ and Manikandan Rajakannu ${ }^{2}$ \\ ${ }^{1}$ Department of Civil Engineering, Kalasalingam Academy of Research and Education, Krishnankoil, \\ Virudhunagar, India \\ ${ }^{2}$ Customer Support Service (Technical), ACC Cements Pvt. Ltd. Bangalore, India
}

\begin{abstract}
Literature review indicates that the usage of mineral admixtures (Fly ash, Ground Granulated Blast Furnace Slag, Silica Fume and Rice Husk ash) significantly improves the durability of concrete structures. Though it is reported as best alternative materials for improving durability of concrete structures, it was not very well received in government projects in India till 1990. However, for the past two decades, the usage of mineral admixtures directly or in the form of blended cement in concrete have significantly increased. Major concern of using mineral admixtures which was persisting among majority of the Ordinary Portland Cement (OPC) users are (i) delayed setting and strength gain, affecting the rate of construction, (ii) inconsistent in quality of mineral admixtures, mostly happened in site blending (iii) no established results pertains to Indian condition. In India, mostly the usage of mineral admixtures in concrete are used as a replacement for OPC, specifically in Ready Mix Concrete and site batching plant. However, few literature have reported that usage of mineral admixtures in the form of blended cement which is made at cement manufacturing plant by either intergrinding or blending will exhibits better concrete properties due to consistent quality and better quality control practice followed. Hence, the authors have undertaken this study to investigate the performance of mineral admixtures (only GGBFS) as direct replacement materials and as blended cement in concrete. In order to understand in detail, both as replacement of OPC and in the form of PSC, was undertaken on various cement content in concrete, i.e., 300, 320, 340, $360,380 \mathrm{~kg} / \mathrm{m}^{3}$. Results of compressive strength at various age of curing indicates that usage of GGBFS in the form of Portland Slag Cement (PSC) shows better performance than as a replacement of OPC in concrete.
\end{abstract}

\section{Introduction}

Literature review indicates that the usage of mineral admixtures (Fly ash, GGBFS, Silica Fume and Rice Husk ash) significantly improves the durability of concrete structures. Though it is reported as best alternative materials for improving durability of concrete

* Corresponding author: c.rameshbabu@klu.ac.in 
structures, it was not very well received in government projects in India till 1990. However, for the past two decades, the usage of mineral admixtures directly or in the form of blended cement in concrete have significantly increased. Major concern of using mineral admixtures which was persisting among majority of the Ordinary Portland Cement (OPC) users are (i) delayed setting and strength gain, affecting the rate of construction, (ii) inconsistent in quality of mineral admixtures, mostly happened in site blending (iii) no established results pertains to Indian condition. In India, mostly the usage of mineral admixtures in concrete are used as a replacement for OPC, specifically in Ready Mix Concrete and site batching plant. However, few literature have reported that usage of mineral admixtures in the form of blended cement which is made at cement manufacturing plant by either intergrinding or blending will exhibits better concrete properties due to consistent quality and better quality control practice followed. Blended cements are produced by inter grinding or blending Portland cement clinker, gypsum and mineral admixtures, i.e., fly ash or GGBFS depending on the type of cement. GGBFS is a by-product from Iron ore processing industry by quenching the molten slag with water to get the sand like glassy particles. When this glassy granulate are grind to very fine particles (mostly less than 10 micron), the reactivity of particles increases and thus ground particles are called as Ground Granulated Blast Furnace Slag (GGBFS). Due to its superior property of converting the liberated calcium hydroxide from Portland cement into Calcium-Silicate-Hydrate during the secondary reaction, it exhibits the superior concrete properties such as low permeability, resistance to chloride and sulphate and corrosion [1]. Literature have reported that up to $80 \%$ of OPC can be replaced with GGBFS to achieve the superior durability performance in concrete subjected to very aggressive environment. Blended cement using GGBFS called as Portland Slag Cement (PSC) are being produced with combination of Portland cement clinker, Gypsum (5\%) and GGBFS (25 to $70 \%$ ) as specified in IS $455-2015$. One of major concern as mentioned above, with usage of GGBFS in concrete is low strength gain as compared to OPC concrete leading to slow in construction activity. However, few researchers have reported that this low strength gain can be overcome by using low water-cement ratio for given replacement level [2]

Qiang et al.[3] reported that the compressive strength of concrete significantly improved after 28 days of curing for the GGBFS replacement level of $15 \%$ and $30 \%$ respectively. Khatri etal. [4] also stated that 35\% GGBFS replacement shows better compressive strength at 28 days. However, Akçaozoglu and Atis[5] have found only marginal improvement in 28-days cured mortar compressive strength for 50\% GGBS replacement. Guneyisi et al.[6] also reported similar observation for $40 \%$ and $60 \%$ replacement level of GGBFS. Few researchers also reported from their research studies that GGBFS in concrete improves the fluidity, reduces bleeding, reduces pore volume and hence better resistance to sulphate and chloride attack on concrete exposed to aggressive environment $[7,8]$

\subsection{Research Significance}

Most of research studies have focused on usage of GGBFS as a replacement of OPC in concrete. However, there is no studies reported on performance of PSC in concrete. This research deals with the evaluating the performance of concrete with OPC and GGBFS and PSC at the same GGBFS level in the concrete. PSC used in this study is composed of $40 \%$ Portland cement clinker, 5\% gypsum and 55\% GGBFS. Hence, OPC plus GGBFS combination in concretes were kept at $45 \%$ OPC $+55 \%$ GGBS. Water cement ratio has been fixed for comparison purpose. 


\section{Experimental programme}

\subsection{Material Used}

Ordinary Portland Cement (OPC-53 conforming to IS: 269 -2015), Portland Slag Cement (PSC conforming to IS: 455 - 2015) and GGBFS having the physical and chemical composition as shown in the Table 1 have been used for the present investigation. River sand and coarse aggregate (both $20 \mathrm{~mm}$ and $12.5 \mathrm{~mm}$ ) used in this investigation have been procured locally from Srivilliputhur, Tamilnadu, India. Aggregate properties, specific gravity, bulk density and sieve analysis are determined as per the procedures mentioned in IS 2386 (shown in Table 2 and 3). Commercially available Sulphonated Naphthalene Formaldehyde (SNF) based high range water reducer was used to maintain the workability in the concrete mix.

Table 1. Chemical composition of OPC, PSC and GGBFS

\begin{tabular}{|c|c|c|c|}
\hline Chemical Analysis & OPC 53 & PSC & GGBS \\
\hline $\mathrm{SiO}_{2} \%$ & 20.52 & 25.66 & 31.86 \\
\hline $\mathrm{Al}_{2} \mathrm{O}_{3} \%$ & 5.58 & 9.78 & 14.97 \\
\hline $\mathrm{Fe}_{2} \mathrm{O}_{3} \%$ & 3.84 & 2.6 & 0.768 \\
\hline $\mathrm{CaO} \%$ & 62.40 & 49.0 & 33.75 \\
\hline $\mathrm{MgO} \%$ & 1.40 & 4.22 & 8.92 \\
\hline Actual $\mathrm{SO}_{3} \%$ & 3.18 & 3.42 & 2.45 \\
\hline $\mathrm{K}_{2} \mathrm{O} \%$ & 1.07 & 0.61 & 0.55 \\
\hline $\mathrm{Na}_{2} \mathrm{O} \%$ & 0.08 & 0.14 & 0.24 \\
\hline $\mathrm{TiO}_{2} \%$ & - & 0.41 & 0.34 \\
\hline $\mathrm{P}_{2} \mathrm{O}_{5} \%$ & - & 0.11 & 0.03 \\
\hline $\mathrm{MnO}_{3} \%$ & - & 0.18 & 0.19 \\
\hline $\mathrm{Cl} \%$ & 0.007 & 0.01 & 0.05 \\
\hline Sulfate & & 0.28 & 1.08 \\
\hline \multicolumn{4}{|l|}{ Physical Analysis } \\
\hline Blaine $\mathrm{m}^{2} / \mathrm{kg}$ & 277 & 340 & 458 \\
\hline R-45 Micron\% & 19.12 & 10.78 & 7.85 \\
\hline
\end{tabular}


Table 2. Properties of aggregates

\begin{tabular}{|l|c|c|c|}
\hline \multirow{2}{*}{ Materials } & \multirow{2}{*}{ River sand } & \multicolumn{2}{|c|}{ Coarse aggregate } \\
\cline { 3 - 4 } & & $20 \mathrm{~mm}$ & $10 \mathrm{~mm}$ \\
\hline Specific gravity & 2.65 & 2.80 & 2.80 \\
\hline Water absorption, $\%$ & 1.40 & 0.40 & 0.40 \\
\hline Fineness modulus & 2.58 & - & - \\
\hline
\end{tabular}

Table 3. Sieve analysis of River sand and Coarse aggregate

\begin{tabular}{|c|c|c|c|}
\hline IS sieve & Weight retained $(\mathrm{g})$ & Cumulative $\%$ retained & Cumulative $\%$ passing \\
\hline \multicolumn{4}{|c|}{ River sand } \\
\hline 4.75 & 25 & 2.5 & 97.5 \\
\hline 2.36 & 25 & 5 & 95 \\
\hline 1.18 & 96 & 14.6 & 85.4 \\
\hline 600 & 313 & 45.9 & 54.1 \\
\hline 300 & 448 & 90.7 & 9.3 \\
\hline 150 & 86 & 99.3 & 0.7 \\
\hline Pan & 7 & - & - \\
\hline \multicolumn{4}{|c|}{ Coarse aggregate $20 \mathrm{~mm}$} \\
\hline 40 & 0 & 0 & 100 \\
\hline 20 & 1406 & 46.17 & 53.13 \\
\hline 10 & 1520 & 97.53 & 2.47 \\
\hline 4.75 & 74 & 100 & 0 \\
\hline \multicolumn{4}{|c|}{ Coarse aggregate $12.5 \mathrm{~mm}$} \\
\hline 16 & 0 & 0 & 100 \\
\hline 12.5 & 85 & 2.83 & 97.17 \\
\hline 10 & 1995 & 69.33 & 30.67 \\
\hline 4.75 & 850 & 97.67 & 2.33 \\
\hline
\end{tabular}

\subsection{Mix Proportions}

The performance of GGBFS in the form of cement, i.e., PSC and as a replacement for OPC in concrete have been studied under two different mix proportions as shown in the Table 4 and 5. For both the mix proportions, various cementitious content have been used, i.e., 300, $320,340,360$ and $380 \mathrm{~kg} / \mathrm{m} 3$. The GGBFS percentage in the second study is arrived based on the GGBFS percentage in PSC which is approximately 55\%. Concrete were made using drum mixer and the slump of concrete after mixing was maintained between 100 to 120 $\mathrm{mm}$. The water content for both the mix were kept constant to study the strength gain tendency. However, the resultant slump drop is being addressed by addition of admixtures, to achieve the target slump. The admixture dosage in the each mix was varied to achieve the target slump of 100 to $120 \mathrm{~mm}$. The compressive strength of concrete was evaluated using $150 \mathrm{~mm}$ cube and each results are average of three specimen. Concrete cubes were demoulded after $24 \mathrm{hrs}$ and the specimens were cured in water tank till testing date. Compressive strength tests were carried out at the end of 1, 3, 7, and 90 days for the concrete cube specimens, using a Compression Testing Machine (CTM) as per IS: 5161959. 
Table 4. Mix proportion for PSC concrete

\begin{tabular}{|c|c|c|c|c|c|c|}
\hline \multirow{2}{*}{ Mix ID } & \multirow{2}{*}{$\begin{array}{c}\text { Cement content, } \\
\mathrm{kg} / \mathrm{m}^{3}\end{array}$} & \multirow{2}{*}{$\begin{array}{l}\text { Water, } \\
\mathrm{kg} / \mathrm{m}^{3}\end{array}$} & \multicolumn{2}{|c|}{ Coarse aggregate, $\mathrm{kg} / \mathrm{m}^{3}$} & \multirow{2}{*}{$\begin{array}{c}\text { Sand, } \\
\mathrm{kg} / \mathrm{m}^{3}\end{array}$} & $\begin{array}{c}\text { Admixture, } \\
\mathrm{kg} / \mathrm{m}^{3}\end{array}$ \\
\cline { 5 - 6 } & 300 & 156 & 722 & 482 & 777 & 2.70 \\
\hline PSC300 & 320 & 160 & 712 & 475 & 766 & 2.88 \\
\hline PSC320 & 340 & 163 & 703 & 468 & 756 & 3.06 \\
\hline PSC340 & 360 & 162 & 698 & 465 & 750 & 3.24 \\
\hline PSC360 & 380 & 152 & 750 & 412 & 754 & 3.42 \\
\hline PSC380 & & & & & \\
\hline
\end{tabular}

Table 5. Mix proportion for $\mathrm{OPC}+\mathrm{GGBS}$ concrete

\begin{tabular}{|c|c|c|c|c|c|c|c|}
\hline \multirow{2}{*}{ Mix ID } & \multirow{2}{*}{$\begin{array}{c}\text { Cement } \\
\text { content, } \\
\mathrm{kg} / \mathrm{m}^{3}\end{array}$} & \multirow{2}{*}{$\begin{array}{c}\text { GGBFS, } \\
\mathrm{kg} / \mathrm{m}^{3}\end{array}$} & \multirow{2}{*}{$\begin{array}{c}\text { Water, } \\
\mathrm{kg} / \mathrm{m}^{3}\end{array}$} & \multicolumn{2}{|c|}{ Coarse aggregate, $\mathrm{kg} / \mathrm{m}^{3}$} & \multirow{2}{*}{$\begin{array}{c}\text { Sand, } \\
\mathrm{kg} / \mathrm{m}^{3}\end{array}$} & $\begin{array}{c}\text { Admixture, } \\
\mathrm{kg} / \mathrm{m}^{3}\end{array}$ \\
\cline { 5 - 6 } OPC-G300 & 135 & 165 & 156 & 774 & 516 & 833 & 2.70 \\
\hline OPC-G320 & 144 & 176 & 160 & 705 & 470 & 758 & 3.84 \\
\hline OPC-G340 & 153 & 187 & 163 & 696 & 464 & 748 & 4.08 \\
\hline OPC-G360 & 162 & 198 & 162 & 690 & 460 & 742 & 4.32 \\
\hline OPC-G380 & 171 & 209 & 152 & 693 & 462 & 745 & 4.56 \\
\hline
\end{tabular}

\section{Results and Discussions}

Figure 1 shows the compressive strength development of PSC300 and OPC-GOPC-G300 concretes at 3, 7, 28 and 90 days. At 3 days, the strength development of PSC concretes was lower than that of OPC-GOPC-G. However, after 7 days, th e compressive strength of PSC concrete was higher than that of OPC-G concretes. At 90 days, there is no significant difference in compressive strength of PSC and OPC-G concretes.

Figure 2 shows the compressive strength development of PSC320 and OPC-G320 concretes at 3, 7, 28 and 90 days. At 3 days, the strength development of PSC concretes was lower than that of OPC-G. However, after 7 days onwards, the compressive strength of PSC concrete was higher than that of OPC-G concretes. At 90 days, there was not much difference in compressive strength of PSC and OPC-G concretes. The strength development pattern is very similar for both 300 and $320 \mathrm{~kg} / \mathrm{m}^{3}$. 


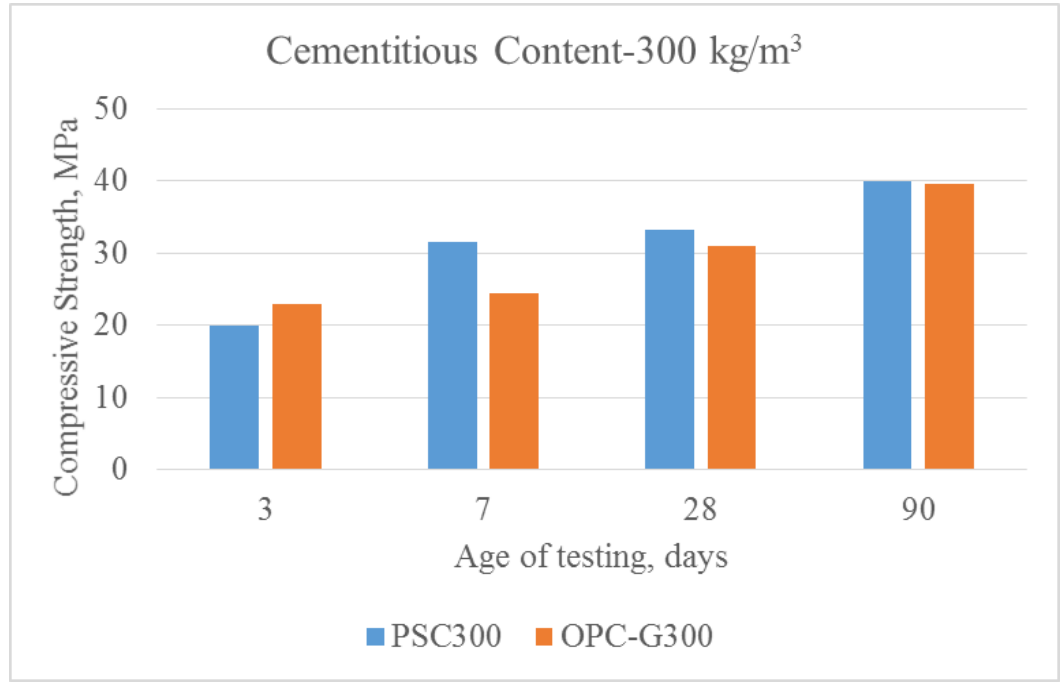

Fig. 1. Compressive strength results of PSC and OPC-G concretes at $300 \mathrm{~kg} / \mathrm{m}^{3}$ cementitious content

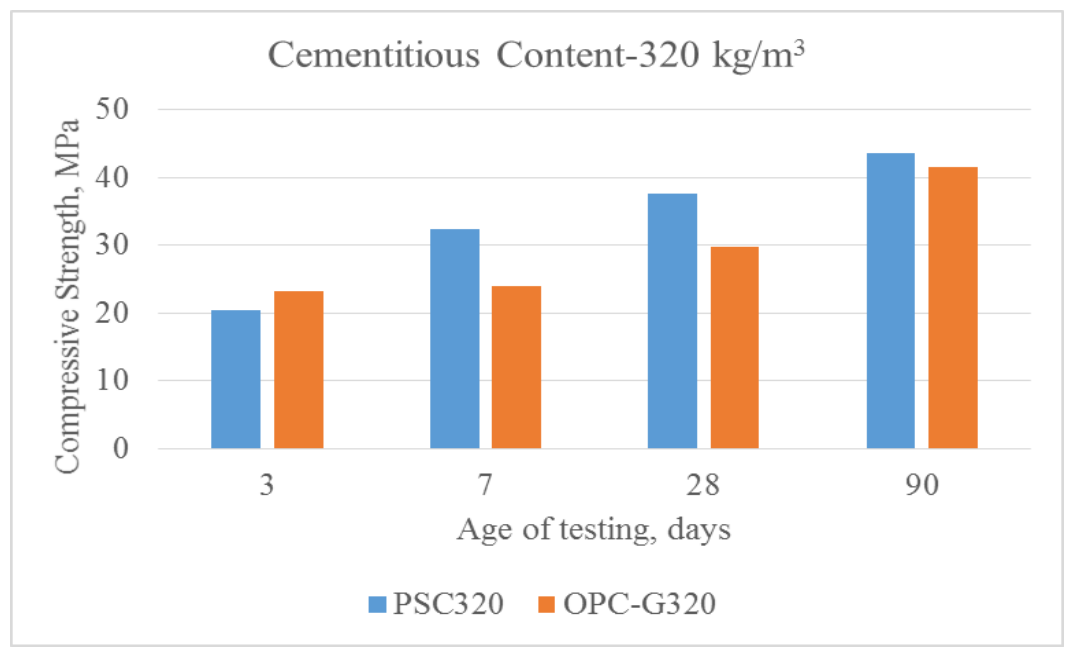

Fig. 2. Compressive strength results of PSC and OPC-G concretes at $320 \mathrm{~kg} / \mathrm{m}^{3}$ cementitious content

Figure 3 shows the compressive strength development of PSC340 and OPC-G340 concretes at 3, 7, 28 and 90 days. At 3 days, the strength development of PSC concretes was slightly higher than that of OPC-G. But from 7 days onwards, the compressive strength of PSC concrete was higher than that of OPC-G concretes. The strength development of PSC concretes was always higher than that of OPC-G concretes at $340 \mathrm{~kg} / \mathrm{m}^{3}$ cementitious content. 


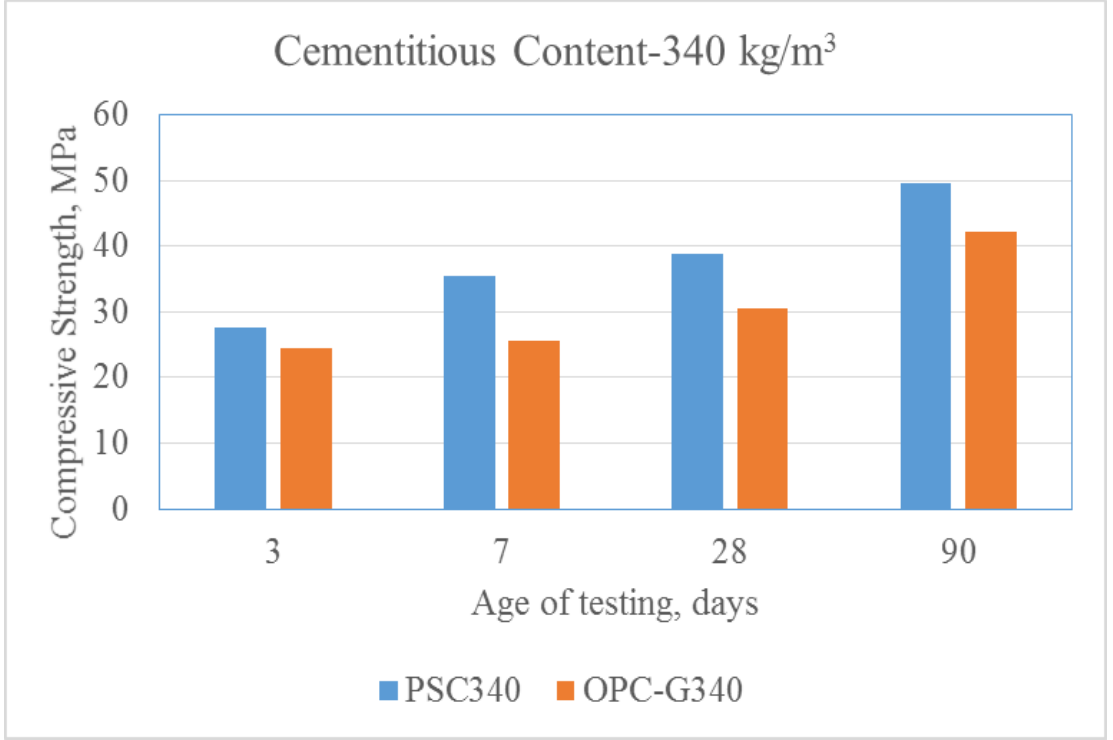

Fig. 3. Compressive strength results of PSC and OPC-G concretes at $340 \mathrm{~kg} / \mathrm{m}^{3}$ cementitious content

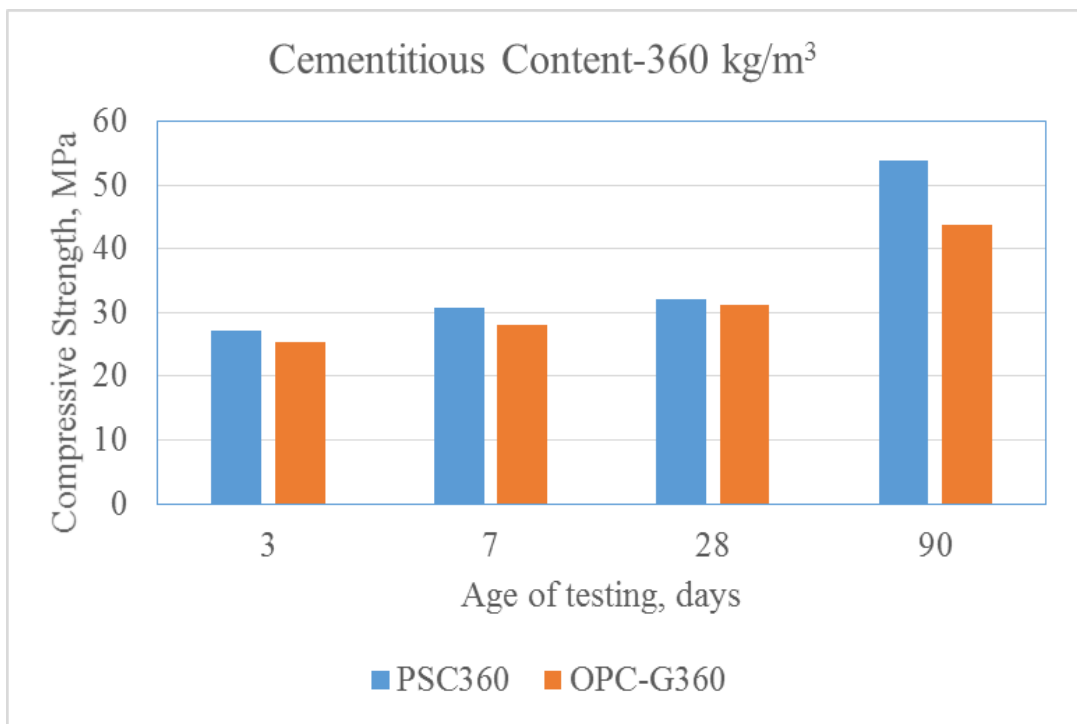

Fig. 4. Compressive strength results of PSC and OPC-G concretes at $360 \mathrm{~kg} / \mathrm{m}^{3}$ cementitious content

Figure 4 shows the compressive strength development of PSC360 and OPC-G360 concretes at $3,7,28$ and 90 days. Similar to $340 \mathrm{~kg} / \mathrm{m}^{3}$ cemenitious content mix, the strength development of PSC concretes was always higher than that of OPC-G concretes at $360 \mathrm{~kg} / \mathrm{m}^{3}$ cementitious content. 
Figure 5 shows the compressive strength development of PSC380 and OPC-G380 concretes at 3, 7, 28 and 90 days. The same trend was followed like $360 \mathrm{~kg} / \mathrm{m}^{3}$ cementitious content. The strength development of PSC concretes was higher at all ages than OPC-G concretes. The difference in strength at 90 days between PSC and OPC-G was higher in cementitious content 360 and $380 \mathrm{~kg} / \mathrm{m}^{3}$. From the results, it has been revealed that at lower cementitious content 300 and $320 \mathrm{~kg} / \mathrm{m}^{3}$ there was not much difference between PSC and OPC-G concretes. But at higher cementitious content such as 340,360 and $380 \mathrm{~kg} / \mathrm{m}^{3}$, the PSC concrete shows higher strength at later ages. From this study, it has been concluded that PSC concretes perfoms better than OPC+GGBS combination, when the replacement level was same in both cases.

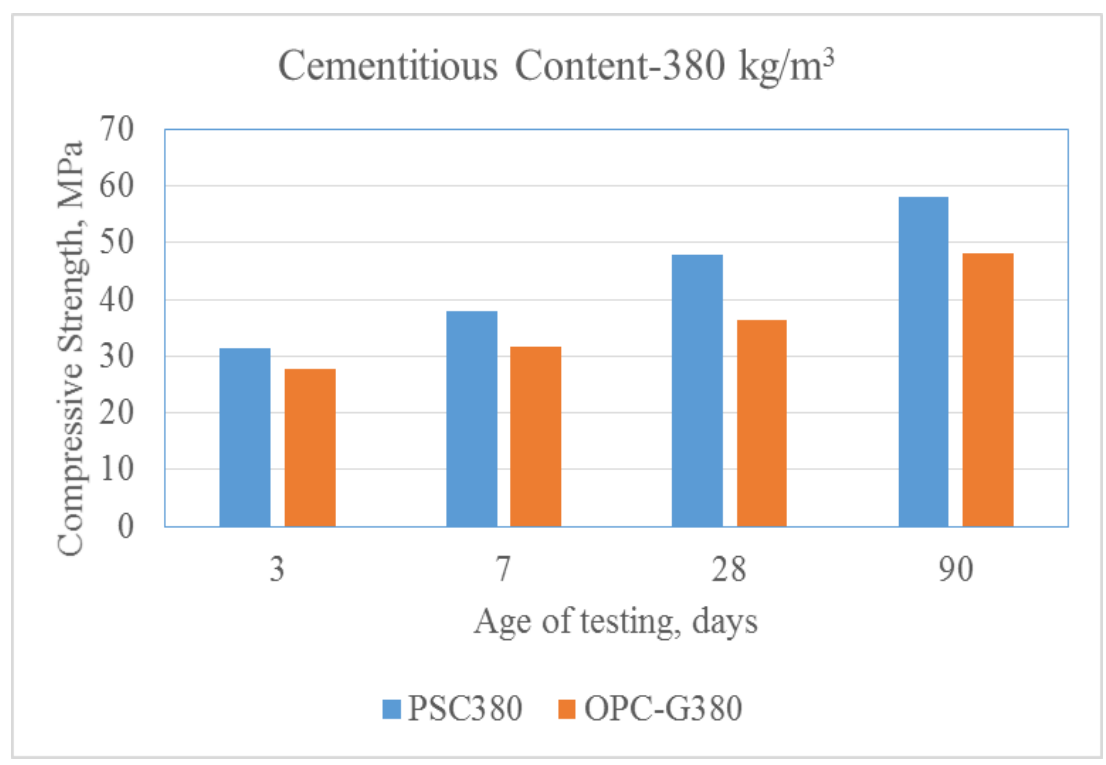

Fig. 5. Compressive strength results of PSC and OPC-G concretes at $380 \mathrm{~kg} / \mathrm{m}^{3}$ cementitious content

\section{Conclusions}

The conclusions drawn from this exerperimental studies and summarised below are applicable to the properties of raw materials used and methodology of investigation adopted.

1. Replacement of OPC with GGBFS in concrete shown relatively low strength development for most of cement content in the concrete as compared to PSC concrete.

2. Use of PSC as cement directly in concrete mix, shown significant strength development for age of curing up to 28 days for most of the cement content.

3. However, at the low cement content i.e., 300 and $320 \mathrm{~kg} / \mathrm{m}^{3}$, the rate of strength development for PSC concrete cured at 3 days shown marginaly low strength gain as compared to OPC and GGBFS concrete.

At higher level of cement content, between 340 to $380 \mathrm{~kg} / \mathrm{m}^{3}$, the compressive strength development at all age of curing, exhibits significant strength development over OPC plus GGBFS concrete. This is mainly attributed to reduced 
vairation in cement quality and optimised quantity of gypsum in the resultant concrete for better strength development.

\section{References}

1. A. Abdel Rahman, S. A. Abo-El-Enein, M. Aboul-Fetouh and K. H. Shehata, Characteristics of Portland blast furnace slag cement kiln dust and active silica, Arabian Journal of Chemistry ,pp1-6. (2011)

2. S. Teng, T.Y.D. Lim, and B.S. Divsholi, Durability and mechanical properties of high strength concrete incorporating ultra fine ground granulated blast furnace slag, Construction and Building Materials, 40, pp875-881 (2013)

3. W. Qiang, Y. Peiyu, Y. Jianwei, and Z. Bo., Influence of steel slag on mechanical properties and durability of concrete, Construction and Building Materials, 47, pp14141420 (2013)

4. R. Khatri, V. Sirivivatnanon, and W. Gross, Effect of different supplementary cementitious materials on mechanical properties of high performance concrete, Cement and Concrete Research, 25, 1, 209-220. (1995)

5. S. Akcaozoglu,and C.D. Atis, Effect of granulated blast furnace slag and flyash addition on the strength properties of light weight mortars containing waste PET aggregates, Construction and Building Materials, 25, pp4052-4058(2011)

6. E. Guneyisi, M. Gesoglu. and E. Ozbay, Strength and drying shrinkage properties of self-compacting concretes incorporating multi-system blended mineral admixtures, Construction and Building Materials, 24, pp1878-1887 (2010)

7. J.M. Gao, C.X. Qian, H.F. Liu, B. Wang, and L. Li, ITZ microstructure of concrete containing GGBS, Cement and Concrete Research, 35, 7, pp1299-1304 (2005)

8. R. Luo, Y. Cai, C. Wang, and X. Huang, Study of chloride binding and diffusion in GGBS concrete, Cement and Concrete Research, 31, 8, pp1-7. (2003)

9. IS 383, Specification for Coarse and Fine Aggregate from Natural Sources for Concrete, Bureau of Indian Standards, New Delhi, India

10. IS 516-1959, Methods of Tests for Strength of Concrete, Bureau of Indian Standards, New Delhi, India

11. IS 2386, Methods of Test for Aggregate in Concrete, Bureau of Indian Standards, New Delhi, India

12. IS 10262-2009, Recommended Guidelines for Concrete Mix Design, Bureau of Indian Standards, New Delhi, India

13. IS 455-1989, Portland Slag Cement - Specifications, Bureau of Indian Standards, New Delhi, India

14. IS 12269-2013, Ordinary Portland Cement, 53 Grade- Specifications, Bureau of Indian Standards, New Delhi, India 